\title{
Student voices in academic writing: PsychLiverpool a community for meaning making
}

\author{
Alex Forsythe \\ University of Wolverhampton, UK \\ Emir Demirbag \\ University of Liverpool, UK \\ Jasmine Warren \\ University of Liverpool, UK
}

\section{Abstract}

The practice and expectations of academic communication are changing and blogging provides a socially liberating mechanism through which to support the development of student writing and literacy. The study reported here examines the impact of an academicstudent partnership in supporting the development of student discourse. Anonymous feedback gathered from both the contributors and readers of the student blog, PsychLiverpool, was analysed using automated text analysis. The analysis identified that high levels of positive emotion were associated with PsychLiverpool. Students valued its capacity to trigger thinking and insight, and the social and networking relationships the blog offered. PsychLiverpool empowered students to expand their learning networks outside their classroom and to peer-network by connecting them with like-minded students and academics. By providing students with safe opportunities to develop their skills and networks, it fulfilled their needs for affiliation and achievement, power, and reward. The particular advantage of PsychLiverpool was that in operating outside traditional university processes of assessment and feedback, students were more motivated to write about and engage with academic language on their own terms.

Keywords: peer networking; blogging; student voice; student partnership.

\section{Introduction}


Good academic writing practice in higher education is established as an essential transferable skill but ensuring that students have good writing skills is often seen as problematic (Lillis and Turner, 2001; Goodfellow, 2005; Bruning and Kauffman, 2015). Developing good writing is a process: from the basics of writing, the development of good syntax, punctuation and spelling; progressing into competencies of argument and structure that differ according to the audience; being both reflective and disciplined to prewrite, write and reformulate; all whilst developing technical skills such as referencing, footnoting, and avoiding plagiarism. Being academically literate also requires students to unpick the nuances of their specific discipline (Badenhorst, 2012), and as students are gradually trained (and socialised) into the ways of researching, thinking, and using discipline-specific language, they often face difficulties in comprehension (Hallett, 2010; White and Lowenthal, 2011). Examples include 'the student told to write an introduction without knowing what an introduction calls for', 'knowing when and how to cite sources', 'the dark art of the scientific abstract', unpicking instructions such as 'be explicit and express your ideas clearly', the avoidance of vague words, and choosing the active or passive voice.

The requirements of discipline-specific language for students is rarely transparent and, as such, difficulties can impact not only on the application of the appropriate academic vocabulary, but also on the activities that stem from their academic vocabulary (Lillis and Turner, 2001). For example, the sourcing of relevant materials, performing evaluative judgements on those materials, then converting those resources into the required activity or assessment by writing clearly and succinctly.

For students in higher education, what counts as knowledge is transmitted through relatively constant (if not, in fact, monotonous) forms of communication (French and Kennedy, 2017). When universities focus on styles of writing that are anonymous and rational, it has been suggested that they inadvertently create students who become asocial seekers of the truth (Hyland, 2009). Students are not afforded the richness of experience that comes through the exploration of their understandings and their preferences, and, as the processes of globalisation impact on our education system, monoglossic language assumptions not only fail to serve our diverse student population but also teach graduates that there are only a few legitimate language practices. It is not surprising then that deficits in student writing skills stunt the development of student identity, can lead to feelings of inadequacy and marginalisation (Kobayashi, Zappa- 
Hollman and Duff, 2017), and inhibit the development of subject matter authority (Badenhorst, 2012; Badenhorst et al., 2015).

Many academics struggle to understand how to help student develop their academic writing (French, 2011; Paré, 2011), often resorting to the recycling of the pedagogies and personal styles of those who taught and supervised them (McAlpine and Amundsen, 2011; Aitchison and Paré, 2012; Guerin, Kerr and Green, 2015; French and Kennedy, 2017). Therefore, it is hardly surprising that students are often writing-reluctant (Asadifard and Koosha, 2013) and disinclined to share their work with academic staff, let alone their peers (Boud, Cohen and Sampson, 1999; Hawe and Dixon, 2017). Despite these challenges, written and verbal discourse continues to play a central role in most academic programmes: 'it is the way that individuals collaborate and compete with others, to create knowledge, to educate neophytes, to reveal learning and define academic allegiances' (Hyland, 2009, p.171). Therefore, academics need to find new approaches to student writing (Lea, 2017).

Considering how quickly students are required to 'get up to speed' with disciplinaryspecific communication, information and communications technology (ICT) can support and improve the student learning experience and the development of good academic literacy (Badenhorst, 2012; Gordon, 2014). ICT can enable writing practice at different levels and in different contexts and is therefore a natural partner of a pedagogy that is flexible, empowering the students to be in control of the when, where, and how of their learning. In this paper we examine the extent to which technology-mediated communication helps break down some of the traditional barriers to the development of academic literacy, by examining its role in supporting students to collaborate, create new knowledge, and develop the capability to make evaluative decisions about the quality of one's own work, and the work of others (Boud et al., 2018).

\section{PsychLiverpool; a community for meaning making}

A significant number of students entering university experience some degree of anxiety in relation to their studies with minor problems having the potential to rapidly impact on their learning and personal well-being (Ibrahim, 2013; Shackle, 2019). This perennial problem 
was a significant driver in our seeking new ways to reach those students and to provide a community for peer support for students of all abilities, where they were free to make meaning from the academic literature in Psychology, apply it to their lives, explore topics that interested them, and build writing and networking skills without the emphasis on academic assessment.

That is why we created the online blog 'PsychLiverpool' and called it a community for meaning making (Silverio and Forsythe, 2018). PsychLiverpool was designed to provide a balance between the many complexities of being a student, accommodating preferences for digital communication, underdeveloped writing skills, evaluation anxiety, need for affiliation, and desire to develop the necessary skills and experience to make them work ready. Given key findings and recommendations surrounding what works to support student retention and success, it was hoped that the blogging initiative would support improvements in student engagement, support students to become more engaged and effective learners, develop their identities as legitimate participants in their future academic communities and therefore improve their future career outcomes (Astin, 1984; Tinto, 1993; Thomas, 2012).

Educators are now using blogs in many ways, including: as online portfolios, for student personal reflective journals, as a record of field notes, as discipline-specific spaces for knowledge sharing, as a space for student dialogue and class administration, and for creating communities of scholarly enquiry and enriching students' learning experiences (Garcia et al., 2015; Carnell and Fung, 2017; Kochoska et al., 2017; Kuo, Belland and Kuo, 2017). The ease of access, immediacy, informality, frequency, and conversational style associated with blogging appears to provide many advantages in supporting learning. These include the opportunity to communicate complex topics to a general audience (Cox and Hollyhead, 2009; Brown \& Woolston, 2018), enrich language skills (Othman et al., 2014), self-reflect (Chen et al., 2005; Bolton, 2014), stress manage (Wang, Lin and Liao, 2012), enrich employability (Longridge, Hooley and Staunton, 2016), teamwork and leadership (Brown \& Woolston, 2018), and encourage citizenship behaviours (Tremayne, 2012). Blogs support students to record their progress chronologically, providing a record of achievement personally and/or professionally contextualised; as such, they promote reflective practice, deep learning, and creative thinking in students (Bartlett-Bragg, 2003; Oravec, 2003; Williams and Jacobs, 2004). Blogs also operate as a successful social 
learning mechanism, developing and supporting communities of practice (Guerin, Carter and Aitchison, 2015). They facilitate group work and increase feelings of inclusivity and interactivity (Dickey, 2004; Williams and Jacobs, 2004) which, it has been argued, may potentially transcend the classroom (Baim, 2004; Halavais, 2006). Blogging is arguably not bounded by psychosocial, cultural conventions (Cox and Hollyhead, 2009), and as such it can help bypass the power and authority relationships that come with academic writing.

In the early days, the introduction of assessed blogs triggered much debate along the lines of 'how are we going to grade this?', particularly when teams of students can be posting on the blogging software up to 15 times per week (Sample, 2010). There were those who went much further, arguing that blogging was not really breaking a mould, because it still tended to be perceived and evaluated in much the same way as the more dominant literacy practices of the academic and professional learning communities (Bourdieu 1991; Goodfellow, 2005) As such, blogging was perceived as doing little more than reinforcing the habitus in academic practice. More recently, a strong argument has emerged that blogging, which is not embedded in peer learning, does not itself create self-reflective communities. Students are rarely motivated to give critical peer feedback when blogs are a required coursework activity, and their participation is largely centred around the activity and feedback of the academic initiating the blog (Specht, 2019).

To address such challenges at PsychLiverpool we created an academic-student partnership which was not linked to any university modular credit or evaluation. The platform provided peer support by creating meaning beyond textbooks, supporting students to explore information about significant topics. Students had the freedom to explore small, nuanced areas of interest, or broader themes, issues, and debates. Students were encouraged to discuss their worries, annoyances, and successes all within a supportive and safe, but public, space, and to critique each other's work. Students benefited from an academic editorial eye and peer review from fellow students, but they also had the liberty to ignore the guidance and critique that comes with a formal academic assessment. The student editors gained publishing experience by preparing the weekly posts, providing feedback to contributors and the other editors, as well as developing highly transferable skills in digital technologies, marketing, and communication. The process transformed the mostly passive style of generating a solo response to an 
academic assignment towards the collaborative and active creation of content, its management, and its dissemination.

This initiative provided an additional extra-curricular activity for students. The initiative would not be assessment driven and therefore had the potential to trigger self-directed learning that would enable students to develop a deeper understanding (Dobozy, 2008; Lemanski, 2011) and enhance the development of professionalism in online environments that are so often associated with distractive and destructive human activities (Thornton et al., 2014; Brooks, 2015; Smith, 2016). The blogging experience may not only enhance academic literacy skills, but may also enhance students' networks and social capital, and foster reciprocity and trust (Vaezi, Torkzadeh and Chang, 2011). PsychLiverpool's virtual nature could improve opportunities for students, increase awareness, and, in particular, raise the aspirations of students from diverse backgrounds who are often less likely to pursue career enhancing extra-curricular activities (Clark et al., 2015). With these goals in mind, rather than operating solely inside the originating Russell Group department, participation in the initiative was widened to include all Psychology students across the four central universities in Merseyside, also including students studying internationally through online programmes.

\section{Evaluation methodology}

To evaluate the impact of PsychLiverpool, over 2500 words were collected anonymously from free text feedback from users of the blog. Students were asked to provide anonymous comments using two methods: (i) the survey platform Qualtrics and (ii) anonymous comments directly through the PsychLiverpool feedback portal. They could also, if they were happy to be identified, provide comments directly to the editor. Contributors $(\mathrm{N}=40)$ were from the four main universities in the Liverpool area (University of Liverpool, Liverpool John Moores University, Liverpool Hope University, and Edge Hill University). Informed consent was sought from the contributors to use their comments in an impact evaluation.

To analyse the comments we utilised Linguistic Inquiry and Word Count (LIWC), a text analysis software that was developed by researchers with interests in social, clinical, 
health, and cognitive psychology, to analyse the language categories capturing people's social and psychological states (Tausczik and Pennebaker, 2010). LIWC is a thematic content analysis system originally designed to discover features of writing that related to negative life experiences (Pennebaker, 1997), but is now used for a wide range of analyses including the study of academic language (Pennebaker, 2011; Pennebaker et al., 2015). A number of LIWC categories are derived from psychological theories (e.g., inhibition words, discrepancy words). The system also captures linguistic dimensions (e.g., percentage of articles, pronouns, word categories), tapping into psychological constructs (e.g., positive and negative emotions, causal words), and personal concern categories (e.g., sex, death). The system can accommodate user-defined dimensions as well.

LIWC calculates the frequency ratings for different categories of words across a wide array of texts (Pennebaker et al., 2015) and then provides an analysis of sentiment through the text classification of a sample of interest. LIWC achieves this by 'reading' a section of given text, counting the percentage of words that reflect different emotions, thinking styles, social concerns, and even parts of speech, and providing data reflecting psychologically meaningful categories. LIWC is then able to convert the themes to data for future analysis. It does this sequentially enabling the researcher to access these themes as they emerge and, if required, store the results in a tab delimited format for future analysis in programmes such as SPSS or Excel. This process enables the researcher to easily identify the categories which are most reflected by the language under examination. Prominent themes will be reflected by a larger number of words relating to the relevant categories.

\section{Impact}

The most prominent sentiment categories resulting from LIWC analysis were 'drives', particularly the networking and social aspects of the community: for example, the need for achievement, power and reward, and cognitive processes around ideas, thinking and insight. Some examples of statements falling into these categories are detailed below: 


\section{Social aspects and relationships}

Here students describe their experiences of blogging in enhancing their networks and in facilitating a sense of community:

"I have had the opportunity to showcase my work which has led to networking with academics outside of my university."

They describe an enhanced sense of belonging and the support of others:

"This blog provides something unique; it helps to connect students across universities, to help them feel like part of a wider research community, something which is very rare in academia."

"It is wonderful to see the Liverpool universities working together to discuss Psychology."

"I feel the idea of a blog creates a community feel and allows people to share ideas and connect with each other."

"I think it will help Psychology students in the area feel connected and that they have a voice."

"It is nice to feel like other students are interested in what I have to say and I look forward to reading about the thoughts and experiences of others."

"It also helps to build those strong links between the various local universities, which is very important in a modern research environment."

"I think the blog's a valuable reminder of the exciting things students and staff are getting up to, which are not usually shared elsewhere."

This sense of community included students who are studying at a distance:

"Browsing the PsychLiverpool blog revealed the blogs of other students either on campus or outside and of overseas students that shared their stories and made me feel more valued [removed for anonymity]. Online studies, even though they have gained a considerable popularity nowadays, may not all the time make you feel like you were a student." 


\section{The need for achievement}

Some students from non-Russell group universities spoke to the editors about the encouragement they gained from their connection with the University of Liverpool and several went on to pursue PhD applications. Some perceived their experience of the blog as a unique opportunity to improve their employability and for others it created a safe space to explore their writing outside the 'high-stakes' of classroom writing:

"Being involved with the online psychological community here at Liverpool is also handy as a way of further developing my written skills and communicating to new/different audiences. Writing pieces for the blog is also a useful way to attempt an alternative writing style without the fear of being marked for it!"

"It's a great opportunity to have a go at writing and sharing my ideas without the pressure of doing an 'academic' piece'."

"The use of guest editors not only gives invaluable and very transferable skills to the students who undertake this, but also helps to showcase their talents".

"Using the psychology blog to inform others about my experience of [removed for anonymity] is important as it allows others to see that fellow students are actively involved in such important simulations."

"I think it is also important for other students who may read the blog as they may feel more motivated to achieve their goals and work harder at university in order to gain more achievements on top of having their final degree."

"It will look good on my CV and it will help me to improve my networking skills."

"I think it is important to raise the profile of the work that I do at university as it shows that I am conscientious, dedicated and determined to achieve my goals."

\section{Thinking and insight}

"I noticed the report on the replicable [sic] of psychological studies last month, really interesting and made me think long and hard about my PhD and the research that is informing it."

"I wasn't aware of the requirements and procedures connected to a career of a psychologist and what was required for a fresh graduate to actually become one. I wanted to but I had no clue how. The section 'careers and jobs' were, 
therefore, the first link that [I] clicked on and it literally opened my eyes and helped me to decide which direction I should follow."

"I find the blog useful for broadening my awareness of wider psychological issues and advances."

"It has given me more confidence in myself and has widened my understanding and enjoyment."

"It helps to facilitate debate and respectful curiosity, which, in my mind, is what helps drive psychological thinking."

\section{Reader interests}

PsychLiverpool's visitor engagement reporting indicates that the impact transcends Psychology as an academic subject. For example, according to the visitor monitoring frequency statistics (at the time of writing), some of the most read articles explored military ethics and the Geneva convention ( $f=5301$ ), the wider academic community $(f=4207$ ), and voluntary work experience for students $(f=3041)$. Blogs exploring the wider academic community include 'Why we are still striking' and 'Reflections on 45 years in Psychology at the University of Liverpool', suggesting that readers are engaging with patterns in academia within the UK that are not conventionally explored within the Psychology curriculum. Further, reader interest in blog topics such as 'Gender inequality in academia' and 'Time's up - The sexualisation of academic conferences' show interest in the academic community globally, which again, is not included in the traditional psychology curriculum. Blogs regarding volunteer experiences, including 'Voluntary opportunities' and 'Why volunteer. Why not. Brew in the field anyone?', offer student readers an insight into the opportunities and experiences of other students around valuable work experience. These, together with blogs such as 'How to help the homeless in Liverpool', guide students towards such extra-curricular experiences within the local community which are important for skills development and are a preparation for future employment.

Readership and student networking have also led to a variety of additional 'guest' bloggers who have covered important topics from specialist perspectives, including honorary professors and practitioners. For example, the human rights campaigner, Peter Tatchell, wrote a piece for PsychLiverpool where he discussed the impact of being attacked in 
Moscow by neo-Nazis and being beaten unconscious by President Mugabe's bodyguards. His writing on PsychLiverpool reached the international LGBT community, prompting students to write to the magazine to discuss their own experiences.

A further significant indicator of success is the partnership that the core 'PsychLiverpool Team' developed with the student editors and contributors. In the past three years, 25 student editors have stayed with the team for more than 12 months; some remain committed alumni who write and seek out opportunities to expand the reach of PsychLiverpool. This initiative has helped develop the social capital of students outside the usual editorial role. These students now work in areas such as postgraduate study, legal research, and humanitarian and community work.

\section{Discussion}

Blogging has become an established tool for developing student writing and stimulating enthusiasm in learning (Bartlett-Bragg, 2003; Oravec, 2003; Williams and Jacobs, 2004; Cox and Hollyhead, 2009; Tremayne, 2012; Wang et al., 2012; Brown \& Woolston, 2018; Othman et al., 2014; Longridge et al., 2016). Student blogs, when included as assessed curriculum activities, have the potential to be significant drivers for change, but students will rarely engage with the blog content for its own sake, particularly when they know that an evaluator will examine the text (Specht, 2019). This potentially creates conflict within the expectations, values, beliefs, and identities that stem from academic discourse both for the student and the academic evaluator because blogging can be a useful tool for writing development, but students have to want to use it.

As we have demonstrated here, good blogging enables students to be in control of the content, the direction and evaluation of their subject discipline, and also to explore how their diverse identities, values, and habits shape their world views and the decisions they make in their lives. In this study, these opportunities were provided outside formal academic activities. Of course, motivating students to take part in non-assessed activities is, in and of itself, a challenge. Here students were engaged, largely by the developmental and networking opportunities that PsychLiverpool offered; they could see key academic and social engagement advantages through supportive peer relations, meaningful 
interactions between staff and students, and a context where they could develop knowledge, confidence, and identity, whilst pursuing interests that were relevant to them and for their future careers.

Supported by examples of student textual comments, we can see that there is undoubtedly a 'feel good' factor about PsychLiverpool. Students could make their voices heard on their own terms, share their experiences, discuss ideas, talk about their dissertations, describe and discuss campus experiences, and connect in a mutually supportive environment. Operating through an enthusiastic network of online learners from different socioeconomic and educational backgrounds and cultures, our Merseyside students are creating university spaces that are becoming 'edgeless' (Bradwell, 2009).

The most notable sentiments encompassed both the academic and social engagement aspects of student belonging, particularly their sense of being accepted, valued, and included (Thomas, 2012). This may in part be explained by the utility and relevance of PsychLiverpool toward the current academic interests and future aspirations of its students. Specifically, the collaborative nature of the network increases students' social capital. For example, students networked outside their lecturers' usual span of control, and for many students this became a critical motivator, which ultimately led to excellent earlycareer outcomes. Secondly, publishing on the blog increased the visibility of the macroand micro-academic achievements that students accomplish, many of which are often lost in a sea of piecemeal assessment. Both of these processes improve opportunities for student employment, further study, increased student self-efficacy, and self-confidence.

The environment created a safe space for students to explore the limits of their academic writing without the high-stakes pressures of the classroom environment. The audience is not 'an assessor' but is instead composed of people who are interested in the content for its own sake. Rather than be judged to be deficient in one skill or another, students could learn disciplinary literacy practices through practising their writing in an authentic way. Students own this discourse, and they share and develop it with other interested students.

The impact of such additional activities on student personal development, academic achievement, communication skills, self-confidence, and self-awareness has been discussed in detail by Clark et al. (2015), but such personal development activities also 
create additional pressures for students, particularly students who are managing complicated lives. Working in an online environment may to some degree mitigate some of the time management and resource challenges that students and academics face, and therefore facilitate the development of the community of practices that can enhance both personal and academic development (Guerin., Carter., and Aitchison 2015).

\section{Implications for programme developers}

Guerin et al. (2015) make a strong case for the inclusion of blogging opportunities within the academic curriculum. Expanding the provision of such opportunities outside the curriculum has demonstrable advantages in reaching students who are outside any single academic's particular span of control. This extended connectivity reduces the reliance on one-way content delivery and improves networking and social capital opportunities for all students, not just those that have social and other advantages which enable them to build impactful employment networks. The outcomes reported here also completement Tinto's (1993) model of student integration and Astin's theory of student involvement (1984). Both theories found that student persistence in their chosen path of study is heavily influenced by the levels of student activity and contact with peers and staff that organisations develop and reinforce. Whilst always challenging to engage students in extra-curricular activities, such initiatives offer students the opportunity to take their learning further (Lemanski, 2011). Taking what students have studied in the classroom and applying it in a range of contexts rewards learning, rather than compliance with assessment standards (Dobozy, 2008).

As universities seek accessible and innovative ways to support student development, the concept of 'open access' can thus be expanded outside the resources that we provide for the advancement of knowledge, to include the mechanisms with which we support our students. Such initiatives have a second strategic advantage as they offer a rich primary source of content that piques student interest, information that is vital as we seek to develop and expand our curriculum offerings, widen access to education, and broaden ideas about what effective and impactful academic discourse can be. 


\section{Conclusion}

The practices and expectations of scholarly communication are changing, and blogging provides a socially liberating mechanism with which to support the development of student writing and literacy. Here we examined the impact of an academic-student partnership, which existed outside any university modular credit or evaluation system, by applying sentiment analysis to anonymous student feedback on PsychLiverpool. Automated text analysis (LIWC) identified high levels of positive emotion, thinking and insight, the need for affiliation, achievement, power, and reward. Blogging enabled students to expand their learning networks outside their classrooms. They developed peer networks and connections with other interested students outside of their usual university network, a process that has the potential to mitigate the dependence on one dominant community of learning, lecturer, or tutor. Students expressed delight at working collegiately with other students and being able to practise their writing development in a safe, unpressurised, but public place, and being rewarded for those contributions through the showcasing of their work. In conclusion, there are considerable academic, professional, and personal benefits to student blog writing. The significant advantage that PsychLiverpool has over other academic blogs was in its situation external to that of the standard university assessment and feedback systems, which meant that students were principally motivated to write and engage with other students on their terms.

\section{References}

Aitchison, C. and Paré, A. (2012) 'Writing as craft and practice in the doctoral curriculum', in Lee, A and Danby, S. (eds.) Reshaping doctoral education International approaches and pedagogies, Abingdon Oxon: Routledge, pp.12-25.

Asadifard, A. and Koosha, M. (2013) 'EFL Instructors and Student Writers' Perceptions on Academic Writing Reluctance', Theory \& Practice in Language Studies, 3(9), pp.1572-1578. 
Astin, A.W. (1984) 'Student involvement: a developmental theory for higher education', Journal of college student personnel, 25(4), pp.297-308.

Badenhorst, C. (2012), 'Academic Literacies and Blog Writing in University Classrooms', in Wankel, C. and Blessinger, P. (eds.) Increasing Student Engagement and Retention Using Online Learning Activities (Cutting-Edge Technologies in Higher Education, Vol. 6 Part A). Bingley: Emerald Group Publishing Limited, pp. 227-254.

Badenhorst, C., Moloney, C., Rosales, J., Dyer, J. and Ru, L. (2015) 'Beyond deficit: Graduate student research-writing pedagogies', Teaching in Higher Education, 20(1), pp.1-11.

Baim, S. (2004) 'Blogs help create learning community', Online Classroom, 2(8), p.5.

Bartlett-Bragg, A. (2003) ‘Blogging to learn', The Knowledge Tree, 4, pp.1-12.

Bolton, G. (2014) Reflective practice: Writing and professional development. London: Sage publications.

Boud, D., Cohen, R. and Sampson, J. (1999) 'Peer learning and assessment', Assessment \& evaluation in higher education, 24(4), pp.413-426.

Boud, D., Ajjawi, R., Dawson, P. and Tai, J. (2018) Developing evaluative judgement in higher education: Assessment for knowing and producing quality work. Routledge: London.

Bourdieu. P. (1991) 'Epilogue: On the Possibility of a Field of World Sociology', in Bourdieu, P. and Coleman, J., (eds.) Social Theory for a Changing Society. Boulder, CO: Westview Press, pp.373-387.

Bradwell, P. (2009) 'The edgeless university: why higher education must embrace technology', UCL, London. Available at: https://dera.ioe.ac.uk/23211/ (Accessed: 4 December 2019). 
Brooks, S. (2015) 'Does personal social media usage affect efficiency and wellbeing?' Computers in Human Behavior, 46, pp.26-37.

Bruning, R. and Kauffman, D.F. (2015) 'Self-efficacy beliefs and motivation in writing development', Handbook of writing research, 2, pp.160-173.

Carnell, B. and Fung, D. (eds.) (2017) Developing the higher education curriculum: Research-based education in practice. London: UCL Press.

Chen, H.L., Cannon, D., Gabrio, J., Leifer, L., Toye, G. and Bailey, T. (2005) 'Using wikis and weblogs to support reflective learning in an introductory engineering design course', Human behaviour in design, 5, pp.95-105.

Brown, E. and Woolston, C. (2018) 'Why science blogging still matters', Nature, 31 January 2018. Available at: https://www.nature.com/articles/d41586-018-01414-6 (Accessed: 4 December 2019).

Clark, G., Marsden, R., Whyatt, J.D., Thompson, L. and Walker, M. (2015) '“It's everything else you do...": Alumni views on extracurricular activities and employability', Active Learning in Higher Education, 16(2), pp.133-147.

Cox. S. and Hollyhead, A. (2009) 'The development of student blogging in higher education', Proceedings of the 2nd international conference of Education, Research and Innovation. Madrid, Spain, 16-18 November, pp.10-21.

Dickey, M. (2004) 'The impact of web-logs (blogs) on student perceptions of isolation and alienation in a web-based distance-learning environment', Open Learning: The Journal of Open, Distance and e-Learning, 19(3), pp.279-291.

Dobozy, E. (2008) 'December. The use and usefulness of non-assessed online learning: Tracking students' behaviour on LAMS', in L. Cameron \& J. Dalziel (eds.), Proceedings of the 3rd International LAMS \& Learning Design Conference 2008: Perspectives on Learning Design, Sydney, Australia: LAMS Foundation, pp. 59-69. 
French, A. (2011) '"What am I Expecting and Why?" How can Lecturers in higher education begin to address writing development for their students?' Journal of Academic Writing, 1(1), pp.228-238.

French, S. and Kennedy, G. (2017) 'Reassessing the value of university lectures', Teaching in Higher Education, 22(6), pp.639-654.

Garcia, E., Elbeltagi, I., Brown, M. and Dungay, K. (2015) 'The implications of a connectivist learning blog model and the changing role of teaching and learning', British Journal of Educational Technology, 46(4), pp.877-894.

Goodfellow, R. (2005) 'Academic literacies and e-learning: a critical approach to writing in the online university', International Journal of Educational Research, 43(7-8), pp.481-494.

Gordon, N. (2014) Flexible pedagogies: Technology-enhanced learning. York: Higher Education Academy.

Guerin, C., Carter, S. and Aitchison, C. (2015) 'Blogging as community of practice: lessons for academic development?', International Journal for Academic Development, 20(3), pp.212-223.

Guerin, C., Kerr, H. and Green, I. (2015) 'Supervision pedagogies: Narratives from the field', Teaching in Higher Education, 20(1), pp.107-118.

Halavais, A. (2006) 'Scholarly blogging: Moving toward the visible college', in A. Bruns and Jacob (eds.) Uses of Blogs, New York: Peter Lang, pp.117-126.

Hallett, F. (2010) 'Study support in higher education: the bifurcation of teaching and learning? Questioning theory-method relations in higher education research'. Paper presented at Education Close Up, Lancaster, United Kingdom, 20-22 July 2010. 
Hawe, E. and Dixon, H. (2017) 'Assessment for learning: a catalyst for student selfregulation', Assessment \& Evaluation in Higher Education, 42(8), pp.1181-1192.

Hyland, K. (2009) Academic discourse: English in a global context. London: Continuum.

Ibrahim, A.K., Kelly, S.J., Adams C.E. and Glazebrook, C. (2013) 'A systematic review of studies of depression prevalence in university students', J Psychiatry Res, 47(3), pp.391-400.

Kobayashi M., Zappa-Hollman S. and Duff P.A. (2017) 'Academic discourse socialization', in Duff P. and May S. (eds.) Language socialization: Encyclopedia of language and education. $3^{\text {rd }}$ edn. Netherlands: Springer, pp.239-254.

Kochoska, J. and Petrovski, J. (2017) 'Blogging in the 21st-century classroom', International Journal of Science and Research (IJSR), 6(1), pp.861864.

Kuo, Y.C., Belland, B.R. and Kuo, Y.T. (2017) 'Learning through blogging: Students' perspectives in collaborative blog-enhanced learning communities', Journal of Educational Technology \& Society, 20(2), pp.37-50.

Lea, M.R. (2017) 'Academic literacies in theory and practice', Literacies and Language Education, pp.147-158.

Lemanski, C. (2011) 'Access and assessment? Incentives for independent study', Assessment \& Evaluation in Higher Education, 36(5), pp.565-581.

Lillis, T. and Turner, J. (2001) 'Student writing in higher education: contemporary confusion, traditional concerns', Teaching in higher education, 6(1), pp.57-68.

Longridge, D., Hooley, T. and Staunton, T. (2013) ‘Building online employability: A guide for academic departments', University of Derby. Available at: http://hdl.handle.net/10545/294311 (Accessed: 4 December 2019). 
McAlpine, L. and Amundsen, C. (2011) Doctoral education: research-based strategies for doctoral students, supervisors and administrators. Netherlands: Springer.

Oravec, J.A. (2003) 'Blending by blogging: Weblogs in blended learning initiatives' Journal of educational media, 28(2-3), pp.225-233.

Othman, H., Wahidin, I.S., Arshad, S.R. and Rahman, K.A. (2014) 'Enriching English language skills via blogging activities for employability skills: A preliminary study', in Proceedings of the Global Conference on Language Practice \& Information Technology, Malaysia, World Conferences.net. Available at: http://worldconferences.net/proceedings/glit2014/toc/papers glit2014/GL\%20090\% 20Haniza\%200thman.pdf (Accessed: 9 December 2019).

Paré, A. (2011) 'Speaking of writing: Supervisory feedback and the dissertation' in Doctoral education: Research-based strategies for doctoral students, supervisors and administrators. Dordrecht: Springer, pp.59-74.

Pennebaker, J.W. (1997) 'Writing about emotional experiences as a therapeutic process', Psychological science, 8(3), pp.162-166.

Pennebaker, J. W. (2011) The secret life of pronouns: What our words say about us. Bloomsbury, New York.

Pennebaker, J.W., Boyd, R.L., Jordan, K. and Blackburn, K. (2015) 'The development and psychometric properties of LIWC2015', Austin, TX: The University of Texas at Austin. Available at:

https://repositories.lib.utexas.edu/bitstream/handle/2152/31333/LIWC2015_Langua geManual.pdf (Accessed: 4 December 2019).

Sample, M. (2010) 'A rubric for evaluating student blogs: the chronical of Higher Education', 27 September. Available at: https://www.chronicle.com/blogs/profhacker/a-rubric-for-evaluating-studentblogs/27196 (Accessed: 4 December 2019). 
Silvero, S. and Forsythe, A.M. (2018) 'Blogging as a pedagogy: The award-winning 'PsychLiverpool Blog' and how it is developing a community for meaningmaking', Psych-Talk, 89, pp.8-10.

Shackle, S. (2019) 'The way universities are run is making us ill; inside the student mental health crisis', 27 September 2019. Available at:

https://www.theguardian.com/society/2019/sep/27/anxiety-mental-breakdownsdepression-uk-students (Accessed: 4 December 2019).

Smith, E.E. (2016) "'A real double-edged sword": Undergraduate perceptions of social media in their learning', Computers \& Education, 103, pp.44-58.

Specht, D. (2019) 'The Issue of Blogging: Using Visual Network Analysis to go Beyond Self-reporting Studies of Blogging', Journal of Learning and Teaching in Digital Age, 4(2), pp.10-24.

Tausczik, Y.R. and Pennebaker, J.W. (2010), 'The psychological meaning of words: LIWC and computerized text analysis methods', Journal of language and social psychology, 29(1), pp.24-54.

Thomas, L. (2012) 'Building student engagement and belonging in higher education at a time of change', Paul Hamlyn Foundation, UK. Available at: https://www.heacademy.ac.uk/system/files/what works final report 0.pdf (Accessed: 4 December 2019).

Thornton, B., Faires, A., Robbins, M. and Rollins, E. (2014) 'The mere presence of a cell phone may be distracting: Implications for attention and task performance', Social Psychology, 45(6), pp.479-488.

Tinto, V. (1993) Leaving college: Rethinking the causes and cures of student attrition. Chicago: University of Chicago Press, USA.

Tremayne, M. (ed.), (2012) Blogging, citizenship, and the future of media. London: Routledge. 
Vaezi, R., Torkzadeh, G. and Chang, J.C.J. (2011) 'Understanding the influence of blog on the development of social capital', ACM SIGMIS Database: the database for Advances in Information Systems, 42(3), pp.34-45.

Wang, Y.S., Lin, H.H. and Liao, Y.W. (2012) 'Investigating the individual difference antecedents of perceived enjoyment in students' use of blogging', British Journal of Educational Technology, 43(1), pp.139-152.

White, J.W. and Lowenthal, P.R. (2011) 'Academic discourse and the formation of an academic identity: Minority college students and the hidden curriculum', Available at:

https://www.researchgate.net/profile/J White3/publication/267954616 Academic D iscourse and the Formation of an Academic Identity Minority College Student $\underline{s}$ and the Hidden Curriculum/links/5460cb170cf27487b4525ea3/AcademicDiscourse-and-the-Formation-of-an-Academic-Identity-Minority-College-Studentsand-the-Hidden-Curriculum.pdf (Accessed: 4 December 2019).

Williams, J. B. and Jacobs, J. (2004) 'Exploring the use of blogs as learning spaces in the higher education sector', Australasian Journal of Educational Technology, 20(2), pp.232-247.

\section{Author details}

Dr Alex Forsythe, CPsych, PFHEA, NTF is a senior academic who specialises in improving work and behavioural skills through self-regulation strategies and by helping individuals develop healthy relationships with feedback. She has spent the last seven years applying these principles in the development of medical professionalism and academic performance. Her work in this area contributed to her winning the prestigious National Teaching Fellowship during 2018, and she was awarded Principal Fellowship of the Higher Education Academy for her national strategic leadership in Higher Education. 
Emir Demirbag is an early career academic interested in the assessment and communication of uncertainty in intelligence to support decision-making, extending to the development and application of tools to support strategic decision-making processes in manufacture. He is also interested in understanding and overcoming psychological barriers to technology adoption. He received a Bachelor of Science degree in Computer Science and Psychology and a master's degree in Advanced Computer Science both at the University of Liverpool. He is currently a doctoral researcher within the School of Electrical Engineering, Electronics and Computer Science and the Department of Psychological Sciences at the University of Liverpool. Emir is PsychLiverpool's Technical Director.

Jasmine Warren is a doctoral researcher in Psychological Sciences at the University of Liverpool working on addiction and sex-specific research, in particular how the menstrual cycle affects alcohol use and mood. Jasmine is PsychLiverpool's Editor-in-Chief. 